\title{
The genus Aphelocheirus Westwood, 1833 (Hemiptera: Aphelocheiridae) in the Iberian Peninsula
}

\author{
JOSÉ ANTONIO CARBONELL ${ }^{1,3}$, PEDRO ABELLÁN ${ }^{1}$, PAULA ARRIBAS ${ }^{1}$, \\ JEAN FRANÇOIS ELDER ${ }^{2} \&$ ANDRÉS MILLÁN ${ }^{1}$ \\ ${ }^{\prime}$ Departamento de Ecología e Hidrología, Facultad de Biología, Universidad de Murcia. Campus Universitario de Espinardo. 30100. \\ Murcia (Spain) \\ ${ }^{2} 2$ Rue de la Cavée. F-50880. La Meauffe (France) \\ ${ }^{3}$ Corresponding author. E-mail: joseantonio.carbonell@um.es
}

\begin{abstract}
This study updates current knowledge of the relationships and geographical distributions of the species from the genus Aphelocheirus in the Iberian Peninsula which, until now, have been involved in nomenclatural and taxonomic confusion. The morphological and molecular analyses presented in this study confirm the taxonomic validity of $A$. murcius and the absence of $A$. aestivalis in the Iberian Peninsula. The shape of the left paramere emerged as the only valid characteristic to differentiate both species. Specimens of Aphelocheirus from northern Spain, previously identified as A. murcius, formed an independent lineage genetically distinct to A. murcius and A. aestivalis, although morphologically indistinguishable from A. murcius.
\end{abstract}

Key words: morphology, DNA identification, taxonomic status, Aphelocheirus, Hemiptera, Iberian Peninsula

\section{Introduction}

Aphelocheirus Westwood belongs to the order Hemiptera Linnaeus, 1758, suborder Prosorrhyncha Sorensen, Campbell, Gill \& Steffen-Campbell, 1995, infraorder Gerromorpha Popov, 1971, superfamily Naucoroidea Leach, 1815 and family Aphelocheiridae Fieber, 1851. Aphelocheiridae is related to family Naucoridae Leach, 1815, but with some clear morphological differences: a thinner, longer rostrum and much less developed front femurs than in Naucoridae (Fig. 1). Its populations show wing polymorphism dominating micropterus form, at least in the southeast of Iberian Peninsula (Millán et al. 1988).

In the Iberian Peninsula, the main habitats of the genus Aphelocheirus are middle and upper reaches of streams and rivers (Fig. 2). The species of this genus seem to be nocturnal, hiding under rock substrates during the daytime (Andersen \& Weir 2004). They are predacious, using their front legs and long rostrum to consume preys, usually mayfly and caddisfly larvae (Nieser et al. 1994). The life cycle of A. aestivalis (Fabricius 1794) was described by Larsen $(1927,1931)$ in Sweden, being three years long.

In the Palearctic Region there are nearly 60 species of Aphelocheirus (Aukema \& Rieger 1995) inhabiting streams and lakes with a depth greater than 10 meters. Along the Western Palearctic Region four species of Aphelocheirus appear. In a large extent of Europe, only occur A. aestivalis, which is widely distributed in medium sections of well-oxygenated and conserved rivers. In the Iberian Peninsula, three species of Aphelocheirus have been cited: A. murcius Nieser \& Millán, 1989 and A. occidentalis Nieser \& Millán, 1989, both Iberian endemics, as well as an A. aestivalis, for which exist only old and unconfirmed records. The fourth species, A. rotroui Bergevin, 1925, is endemic of Morocco. This species is known by a male macropterus specimen from the National Park of Tazza, collected at night with a light-trap (Bergevin 1925), and unfortunately not available for our study.

The two Iberian endemic species described (Nieser \& Millán 1989) have clear differences between them. Conversely, A. aestivalis, with a European distribution and the only species of this genus cited to the Iberian Peninsula until 1989, is very similar to A. murcius and some taxonomic specialists showed reasonable doubts about the valid- 
ity of this latter species (M. Baena pers. com.). Thus, a review of the morphological characteristics and genetic differentiation of species is necessary to elucidate this controversy. Therefore, the main goal of the present work is to revise and diagnose genetically and morphologically the species of the genus occurring in the Iberian Peninsula. The results of this revision will allow us to (1) elucidate the taxonomic validity of $A$. murcius; (2) to determine the real presence of $A$. aestivalis in Iberian Peninsula; and (3) to update the current knowledge of the relationships and geographical distributions of the species, which, in view of the nomenclatural and taxonomic confusion, is outdated.

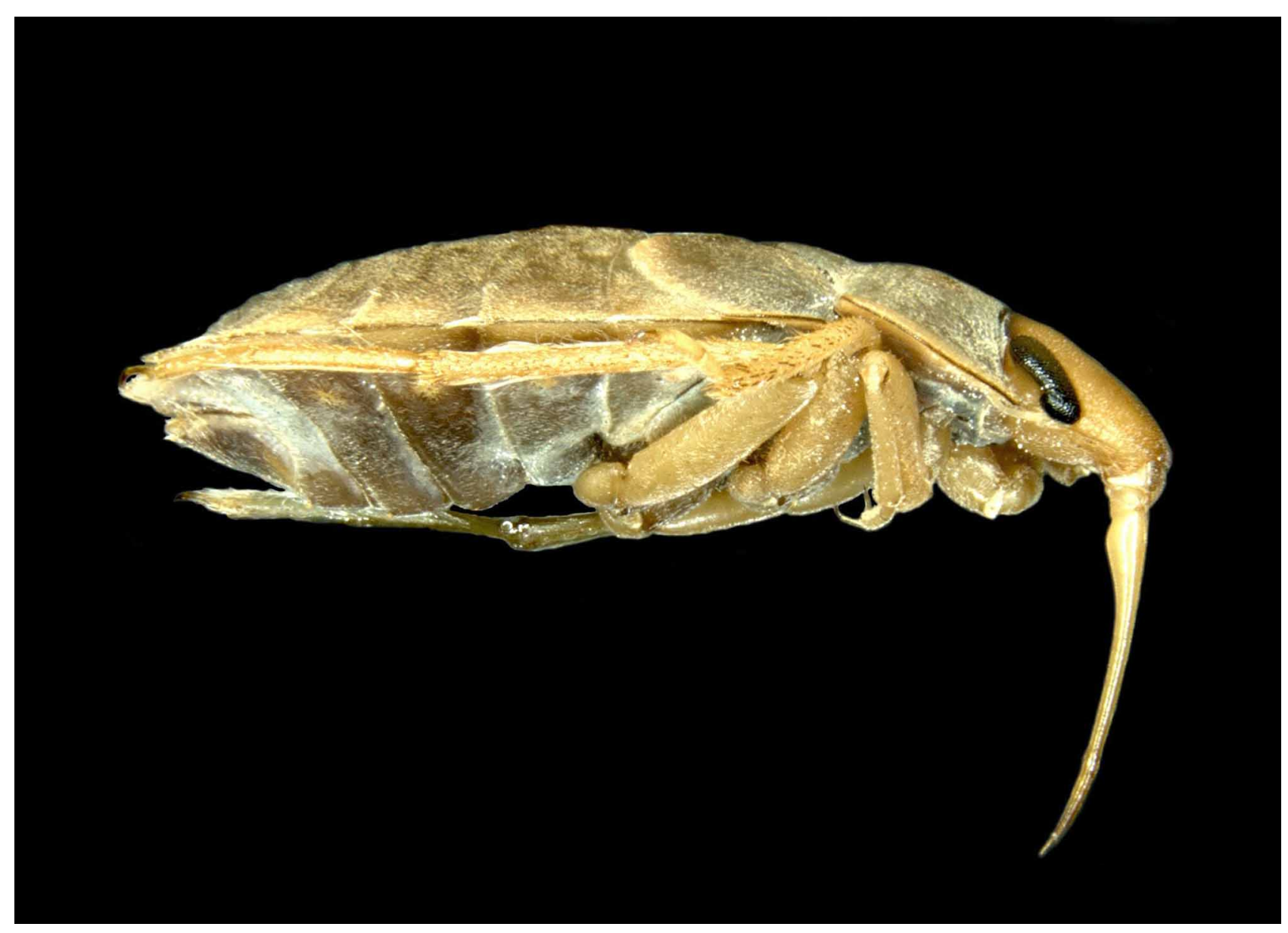

FIGURE 1. Aphelocheirus aestivalis. With flattened body and long rostrum.

\section{Material and methods}

Data set. An exhaustive bibliographic review of the genus Aphelocheirus in the Iberian Peninsula (Fernández 1982; Nieser \& Montes 1984; Murillo 1985; Millán et al. 1988; Nieser \& Millán 1989; Aukema \& Rieger 1995; López et al. 1995; Nieser et al. 1994; Millán et al. 2002; Salamanca et al. 2002; Miguélez \& Valladares 2006), private collections of specimens (D.T. Bilton, A. Castro, D. Miguélez, A. Mellado, I. Ribera and E. Rico collections), and own field surveys were used.

Morphological analysis. Material examined previously identified as A. occidentalis: Paratype: $1 \hat{\jmath}, 12 / 07 /$ 1987, Umia River, Portas, Pontevedra (Spain), leg. A. Cordero. Department of Ecology and Hydrology, University of Murcia.

Other material: 2 †, 08/05/1993, Áncora River, Viana do Castelo (Portugal), leg. D. T. Bilton; 1 q, 24/07/ 1998, Áncora River, Viana do Castelo (Portugal), leg. I. Ribera; 1 đૈ, 25/07/2000, Estena River, Toledo (Spain), leg. P. Aguilera; 1 ð, 30/07/2001, Bronova River, Guadalajara (Spain), leg. M. Navarro; 1 and 2 ๆ, 13/05/2002, Pusa River, Toledo (Spain), leg. J. L. Moreno; 1 § and 1 o; 21/05/2002, Sorbe River, Guadalajara (Spain), leg. J.

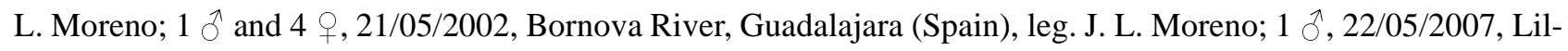


las River, Guadalajara (Spain), leg. F. Picazo; 1 $\precsim$, 20/05/2009, Navia River, Lugo (Spain), leg. A. Mellado; 2 , 09/05/2009, Lamas River, Lugo (Spain), leg. A. Mellado; 1 ô and 1 + , 09/09/2009, Lamas River, Lugo (Spain), leg. A. Mellado; $1 \lesssim$ and 1 + , 09/09/2009, Navia River, Asturias (Spain), leg. A. Mellado.

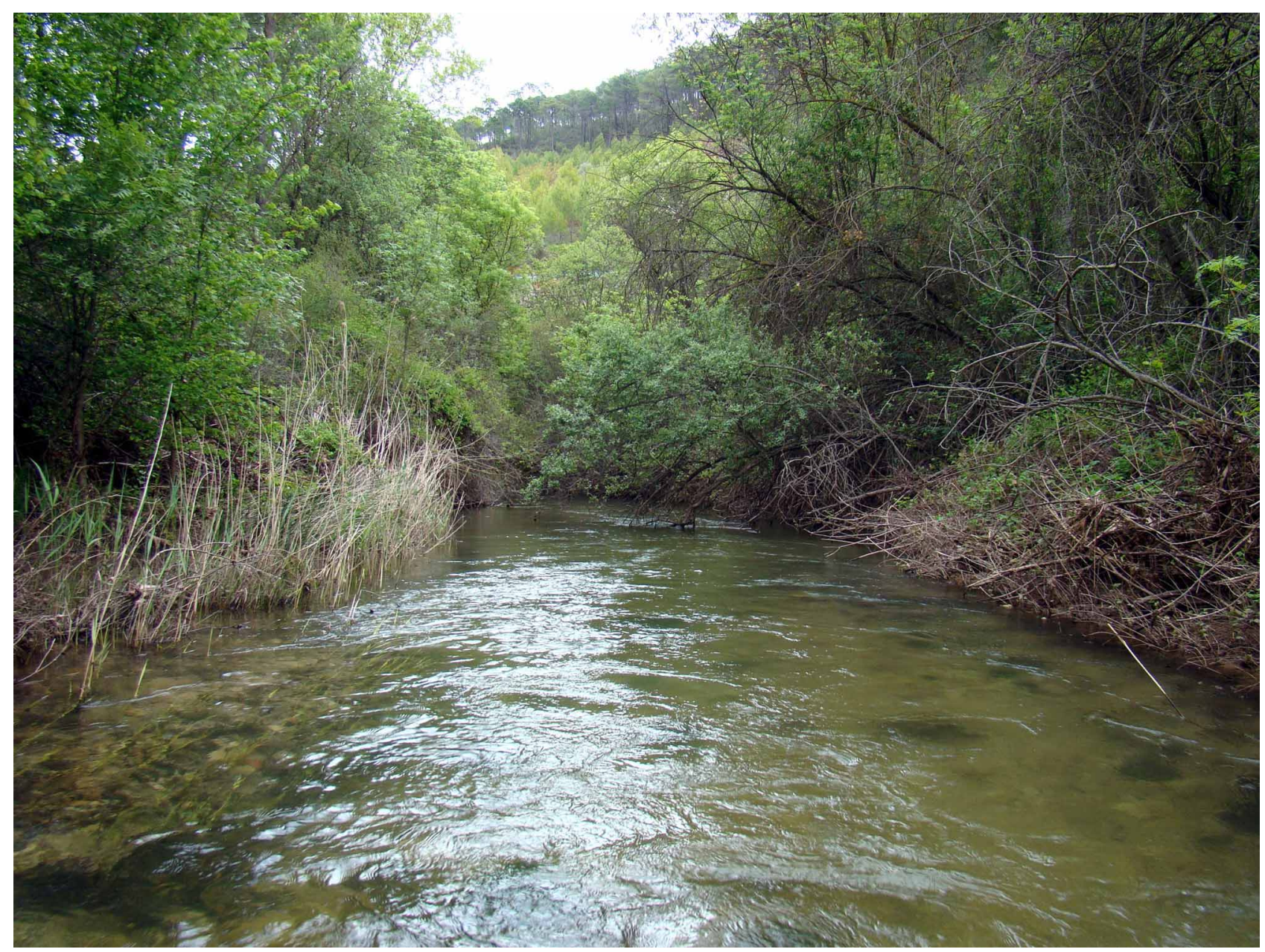

FIGURE 2. Typical habitat of Aphelocheirus. Mundo river (Albacete).

Material examined previously identified as A. murcius: Paratype: $1 \AA$, 20/03/1983, Mundo River, La Altera, Albacete (Spain), leg. Montes et al. Department of Ecology and Hydrology, University of Murcia.

Other material: 2 ก, 13/06/1988, Urola River, Guipúzcoa (Spain), leg. E. Rico; 1 Oૈ, 27/04/1997, Tus River, Albacete (Spain), leg. I. Ribera; 2 and 2 + , 19/09/2001, Tus River, Albacete (Spain), leg. J. L. Moreno; 1 ond 4 q, 30/08/2007, Genal River, Málaga (Spain), leg. by Castro et al.; 12 đ and 4 , , 09/07/2008, Ebro River, Burgos (Spain), leg. D. Miguélez \& L. F. Valladares; 2 đ and 2 †, 09/04/009, Tus River, Albacete (Spain), leg. P. Abellán \& N. Martínez; 2 +, 28/04/2009, Mundo River, Albacete (Spain), leg. A. Millán \& J.A. Carbonell; $3 \widehat{\bigcirc}$ and 3 q, 03/08/2010, Tus River, Albacete (Spain), leg. Belmar et al.; 9 and 6 †, 02/09/2010, Ebro River, Burgos (Spain), leg. Millán et al.

Material examined previously identified as A. aestivalis: 1 o and 3 , , 03/06/1995, Lessay (France), leg. J. F. Elder; $2 \delta$ and 11 , 12/04/2001, Fozzano (Corsica), leg. J. F. Elder; 1 and 1, , 29/09/2001, Arzano (France), leg. J. F. Elder; 3 ô and 3 क, 30/04/2009, West Dorset (England), leg. F. Picazo; 1 ot and 2 q, 02/05/2009, Nort Devon (England), leg. F. Picazo (all specimens preserved in 70\% ethanol except 2009 specimens preserved in absolute ethanol). Furthermore, we studied dry preserved material (12 specimens: 9 and 3 क $)$ from different localities of French Manche, Orne and Côtes-d'Armor (leg. J. F. Elder): 1 +, 17/07/1978, Lessay; 2 đ, 22/06/ 1992, La Feuillie; $1 \hat{\partial}, 17 / 05 / 1997$, Kairon; 1 ㅇ, 21/05/1997, Montpinchon; $2 \hat{\jmath}, 08 / 05 / 2000$, Vidouville; $1 \hat{\partial}$ and

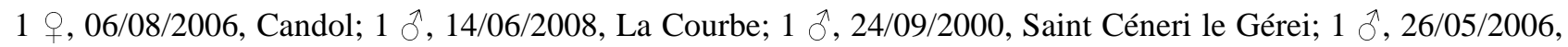
Saint-Hervé. 
Molecular analysis. To elucidate the taxonomic validity of $A$. murcius, the phylogenetic relationships between this species and A. aestivalis were studied. A total of 11 specimens of both species were selected from 10 localities (Table 1). 5 populations of A. aestivalis from France and England as well as populations from throughout the complete known distribution range of A. murcius were sampled. Populations of $A$. occidentalis from the centre of the Iberian Peninsula were used as an outgroup taxa. Samples were collected in the field and kept in absolute ethanol until processing. DNA was extracted using Invisorb Spin Tissue Mini Kit (Invitek, Berlin, Germany). One mitochondrial (5' end of cytochrome c oxidase subunit 1; $\operatorname{cox} 1)$ gene fragment was sequenced using C1-J-2183 and L2N-3014 primers (Simon et al. 1994). Sequencing was done using the ABI PRISM BigDye Terminator Cycle Sequencing kit (Applied Biosystems) and sequenced products were electrophoresed on ABI 310 and 3700 automated sequencers (Applied Biosystems). They were then assembled and edited with Sequencher 4.7 (GeneCodes Corporation) and submitted to GenBank (see Table 1 for Accession numbers).

TABLE 1. Material used in the molecular analysis, with species, locality, country, number of individuals (N. ind.), collector (Leg.), DNA voucher and GenBank Accesion Number (Accession n.). A. sp. corresponds to individuals previously identified as A. murcius.

\begin{tabular}{|c|c|c|c|c|c|c|}
\hline Species & Locality & Country & N. ind. & Leg. & DNA voucher & Accession $\mathrm{n}$. \\
\hline A. $\mathrm{sp}$ & Ebro river (Pesquera de Ebro, Burgos) & Spain & 1 & A. Millán et al. & IBE-AB337 & HQ738307 \\
\hline A. sp & Ebro river (Pesquera de Ebro, Burgos) & Spain & 1 & A. Millán et al. & IBE-AB339 & HQ738308 \\
\hline A. aestivalis & La Drôme river (Balleroy, Calvados) & France & 1 & J.F. Elder & IBE-AB292 & HQ738309 \\
\hline A. aestivalis & Le Noireau river (Berjou, Orne) & France & 1 & J.F. Elder & IBE-AB293 & HQ738310 \\
\hline A. aestivalis & La Sienne (S. Denis le Gast, La Manche) & France & 1 & J.F. Elder & IBE-AB291 & HQ738311 \\
\hline A. aestivalis & L'Airou (Ver, La Manche) & France & 1 & J.F. Elder & IBE-AB270 & HQ738312 \\
\hline A. aestivalis & Taw river (Umberleigh, Nort Devon) & England & 1 & F. Picazo & IBE-PA310 & HQ738313 \\
\hline A. murcius & Genal river (Algatocín, Málaga) & Spain & 1 & A. Castro et al. & IBE-AB271 & HQ738314 \\
\hline A. murcius & Guadaiza river (S.de Alcántara, Málaga) & Spain & 1 & A. Castro et al. & IBE-AB294 & HQ738315 \\
\hline A. murcius & Tus river (Yeste, Albacete) & Spain & 1 & $\begin{array}{l}\text { P. Abellán \& N. } \\
\text { Martínez }\end{array}$ & IBE-PA301 & HQ738316 \\
\hline A. murcius & Mundo river (La Alfera, Albacete) & Spain & 1 & $\begin{array}{l}\text { A. Millán \& J.A. } \\
\text { Carbonell }\end{array}$ & IBE-PA302 & HQ738317 \\
\hline $\begin{array}{l}\text { A. occiden- } \\
\text { talis }\end{array}$ & $\begin{array}{l}\text { Bornova river (Gascueña de Bornova, } \\
\text { Guadalajara) }\end{array}$ & Spain & 1 & J.L. Moreno & IBE-AB272 & HQ738318 \\
\hline
\end{tabular}

The optimal evolutionary model was estimated prior to analysis with jModel-Test (Posada 2008). Bayesian analyses (BA) were conducted on a combined data matrix with MrBayes 3.1.2 (Huelsenbeck \& Ronquist 2001, Ronquist \& Huelsenbeck 2003). MrBayes ran for $10 * 10^{6}$ generations using default values, saving trees each 100 . "Burn-in" values were established after visual examination of the standard deviation plot of the split frequencies between two simultaneous runs. An additional phylogenetic approach was calculated for comparative purposes, using Maximum Likelihood (ML) with a genetic algorithm implemented in RaxML 7.0.3 (Stamatakis 2006) using an estimated GTR+gamma model for the combined sequence and the default settings. Node support was measured with posterior probabilities in MrBayes, and 1000 bootstrap replicates using the rapid RaxML bootstrapping algorithm (Stamatakis et al. 2008).

\section{Results}

\section{Phylogenetic relationships}

Both reconstruction methods (Bayesian probabilities and Maximum Likelihood) produced similar tree topology, with comparable support for most nodes (Fig. 3). A. murcius from southern populations and A. aestivalis appeared in two independent and well-supported clades, forming a monophyletic group with strong support. In turn, this 
group was a sister of a clade (designed as Aphelocheirus sp. in Fig. 3) containing individuals from the northern Iberian Peninsula previously morphologically assigned to A. murcius (Carbonell \& Millán 2010).

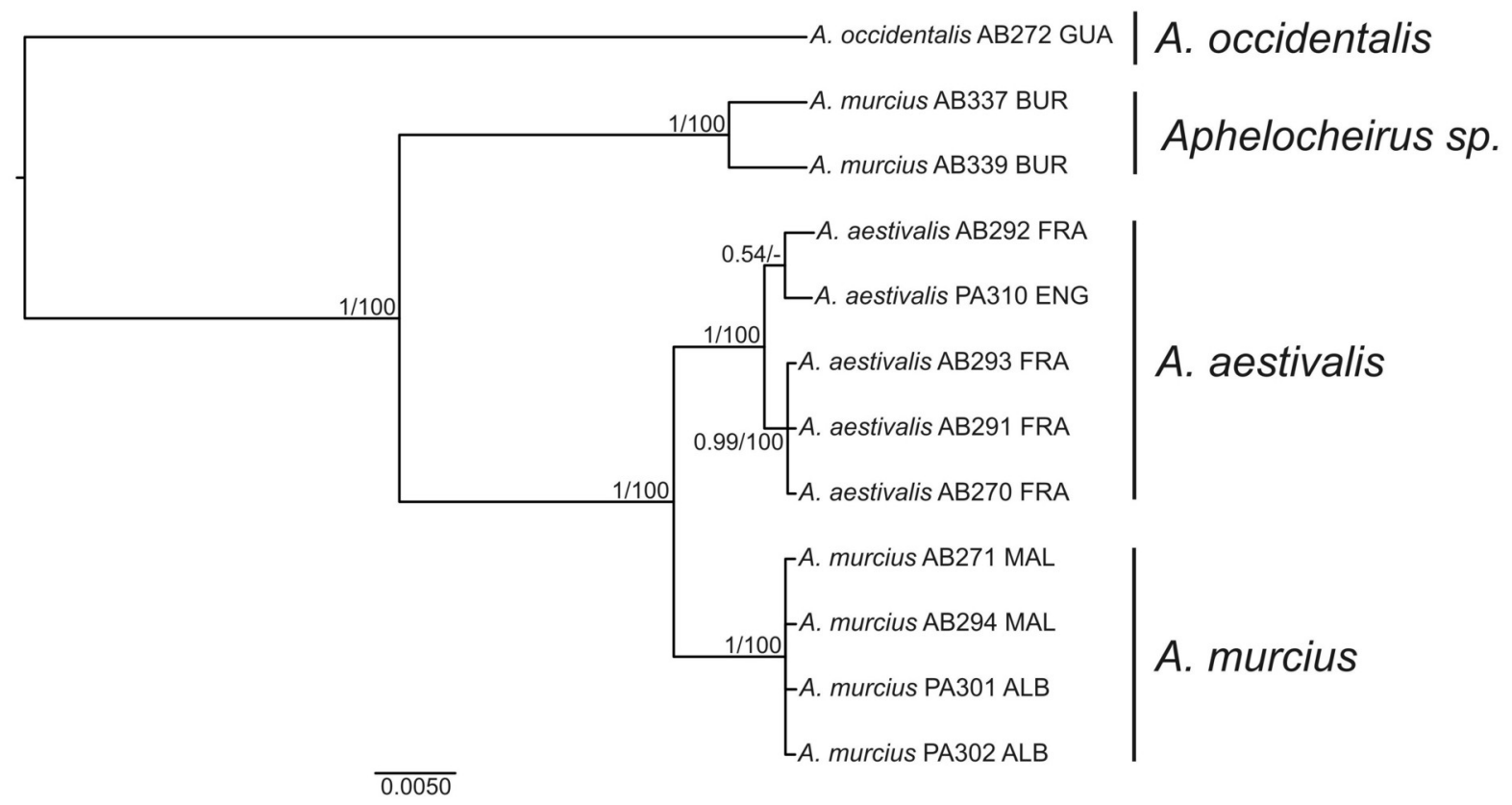

FIGURE 3. Phylogram obtained with MrBayes and mitochondrial data. In nodes, Bayesian posterior probabilities / boostrap support values in RaxML (when $>50 \%$ ).

\section{Morphological diagnosis}

\section{Aphelocheirus occidentalis Nieser \& Millán, 1989}

Short description: water bug with a flat, oval body and length between 9.2 and $9.8 \mathrm{~mm}$ (Fig. 4A). The principal difference between other Aphelocheirus species is the form of the abdominal conexives 3 to 5, which are very long and pointed. Colour: head, including antennae, yellowish, eyes blackish, anterior and posterior margin dorsally blackish. Dorsally dark greyish thorax and abdomen with narrow yellowish margins. Yellow legs. Genitalia: both parameres with rounded heel (Fig. 4C,D). Penis without lateral spines in apical part (Fig. 4B).

\section{Aphelocheirus murcius Nieser \& Millán, 1989}

Short description: water bug with a flat oval body and length between 8.1 and $9.1 \mathrm{~mm}$ (Fig. 5A). Colour: head, including antennae, yellowish, eyes blackish. Dorsally greyish thorax and abdomen, usually with broad yellowish lateral bands and yellowish marks in pronotum and posterio of abdomen. Yellow legs. Genitalia: heel of left paramere pointed, right paramere long and thin with rounded heel (Fig. 5C,D). Penis with lateral spines in apical part (Fig. 5B).

\section{Aphelocheirus sp. (north Iberian populations)}

Short description: Specimens from Northern Iberia previously assigned to A. murcius. Water bug with a flat oval body and length between 8.1 and $9.1 \mathrm{~mm}$. Colour: head, including antennae, yellowish, eyes blackish. Dorsally greyish thorax and abdomen, sometimes with broad yellowish lateral bands and yellowish marks in pronotum and posterio of abdomen. Yellow legs. Genitalia: heel of left paramere pointed (Fig. 6A), right paramere long and thin with rounded heel. Penis with lateral spines in apical part. 
These specimens do not present any clear morphological differences with those from populations of A. murcius of South-east of Iberian Peninsula. After genitalia study we did not find significant differences in the shape of left paramere (Fig. 6A,B).

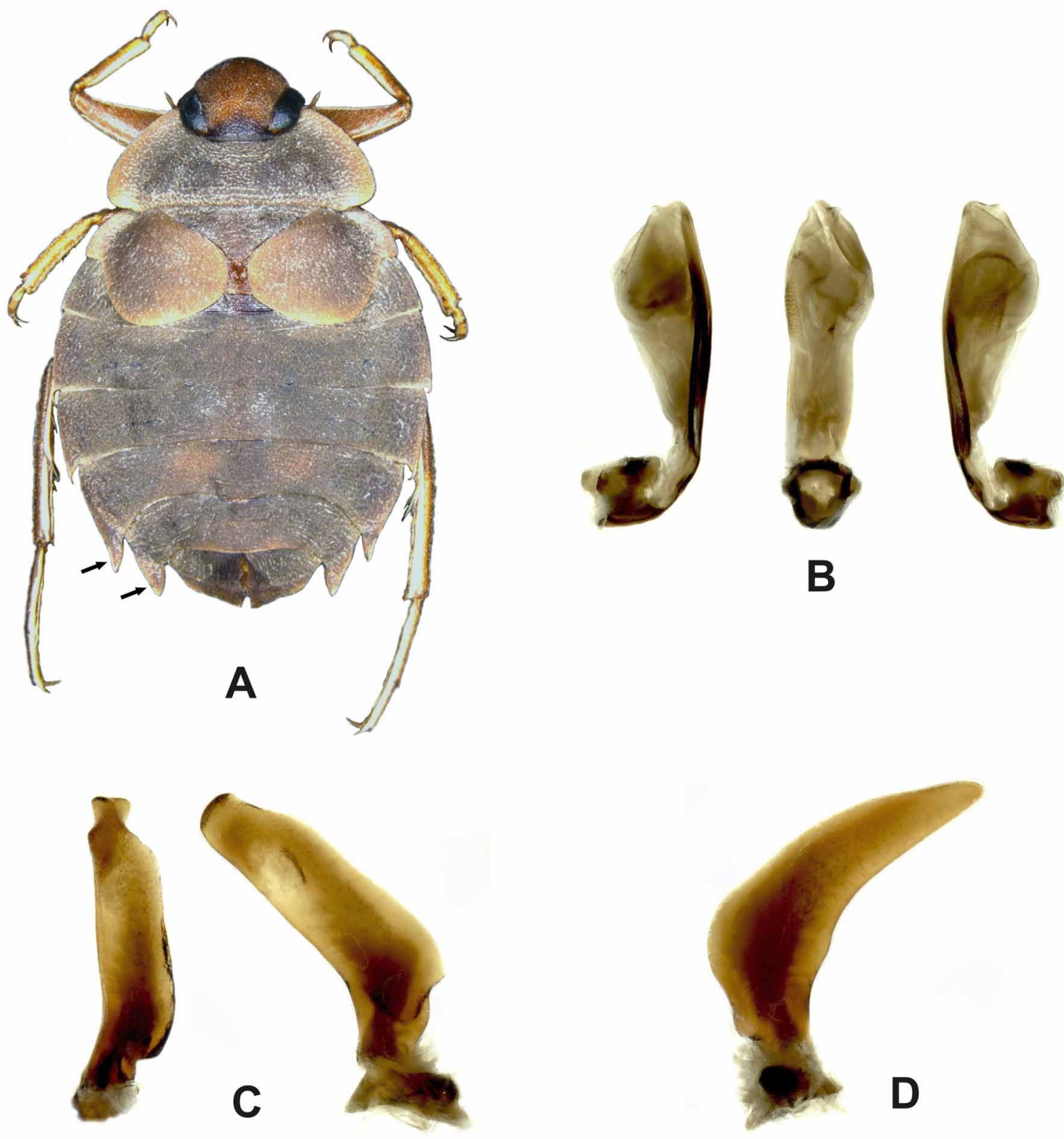

FIGURE 4. Aphelocheirus occidentalis. A) habitus; B) penis (ventral and lateral view); C) Left paramere (dorsal and lateral view); D) right paramere.

\section{Aphelocheirus aestivalis (Fabricius, 1794)}

Short description: water bug with a flat, oval body and length between 8.5 and $10 \mathrm{~mm}$ (Fig. 7A). Colour: head, including antennae, yellowish, eyes blackish. Dorsally greyish thorax and abdomen, sometimes with broad yellowish lateral bands and yellowish marks in pronotum and abdomen. Yellow legs. Genitalia: both parameres with rounded heels (Fig. 7C,D). Penis with lateral spines in apical part (Fig. 7B). 

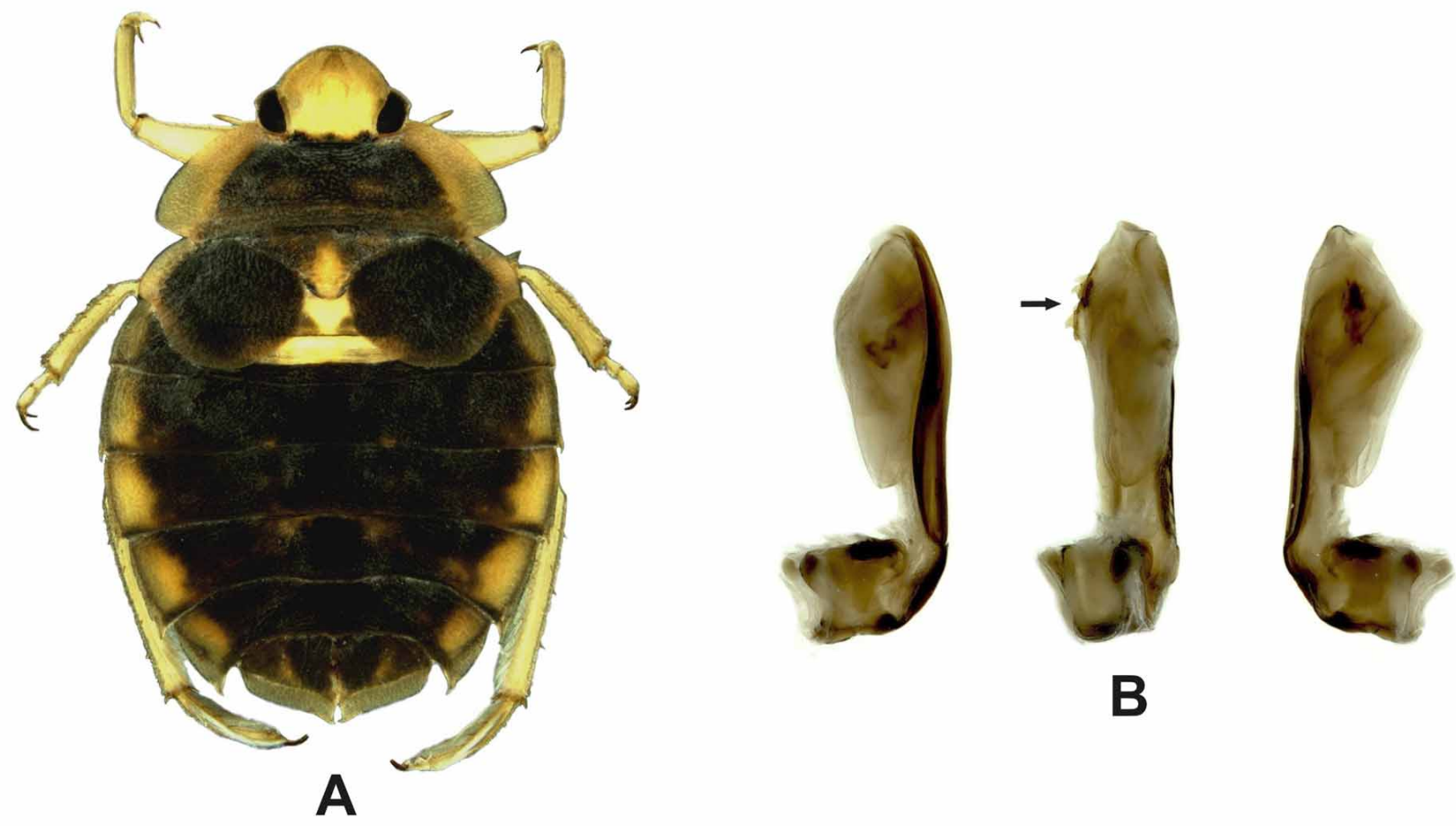

\section{B}
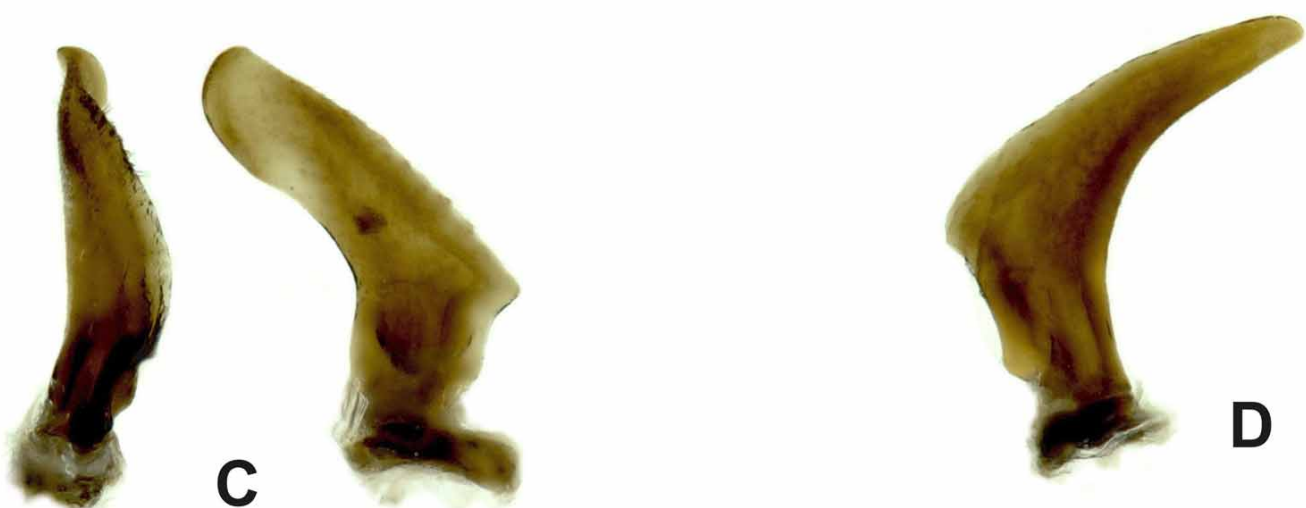

FIGURE 5. Aphelocheirus murcius. A) habitus; B) penis (ventral and lateral view); C) Left paramere (dorsal and lateral view); D) right paramere.

\section{Iberian distribution}

A. occidentalis: Iberian endemic of north and central Spain and north of Portugal: A Coruña, Ourense, Pontevedra, Lugo, Asturias, León, Madrid, Toledo, Guadalajara, Viana do Castelo and Vila Real (Fig. 8). Table 2 shows the Iberian records of A. occidentalis.

$1^{\text {st }}$ record in the Iberian Peninsula: Nieser \& Millán (1989).

A.murcius: Iberian endemic distributed in south and south-east of the Iberian Peninsula: Albacete, Cádiz and Málaga (Fig. 8). Table 3 shows the Iberian records of A. murcius.

$1^{\text {st }}$ record for the Iberian Peninsula: Segura River basin, Nieser \& Millán (1989). 
TABLE 2. Iberian records of A. occidentalis.

\begin{tabular}{|c|c|c|c|c|c|c|c|}
\hline Country & Province & Locality & River & Date & Collected by & U.T.M. & Alt. (m) \\
\hline Spain & Pontevedra & Pontevedra & Almofrei & $29 / 08 / 1984$ & A. Cordero & 29TNG39 & 40 \\
\hline Spain & Pontevedra & Pontevedra & Fontanes & 02/07/1985 & A. Cordero & 29TNH30 & 160 \\
\hline Spain & Pontevedra & Portas & Umia & 26/07/1986 & A. Cordero & $29 \mathrm{TNH} 21$ & 60 \\
\hline Spain & Pontevedra & Portas & Umia & 12/07/1987 & A. Cordero & $29 \mathrm{TNH} 21$ & 60 \\
\hline Spain & A Coruña & Sigueiro & Tambre & $10 / 1983$ & J. Murillo & 29TNH45 & 200 \\
\hline Spain & A Coruña & Oroso & Lengüelle & $10 / 1983$ & J. Murillo & 29TNH46 & 200 \\
\hline Spain & Ourense & Viana del Bollo & Bibey & 11/05/1987 & N. Nieser & 29TPG56 & 800 \\
\hline Spain & Lugo & Navia de Suarna & Navia & 20/05/2009 & A. Mellado & 29TPH65 & 350 \\
\hline Spain & Lugo & Navia de Suarna & Lamas & 09/05/2009 & A. Mellado & 29ТРН66 & 500 \\
\hline Spain & Lugo & Navia de Suarna & Lamas & 09/09/2009 & A. Mellado & 29TPH66 & 500 \\
\hline Spain & Lugo & Navia de Suarna & Rao & $20 / 05 / 2009$ & A. Mellado & 29TРH66 & 300 \\
\hline Spain & Asturias & Ibias & Navia & 09/09/2009 & A. Mellado & 29TРH66 & 450 \\
\hline Spain & León & Albares de la Ribera & Boeza & 31/08/1994 & F. García-Criado & 29TQH12 & 700 \\
\hline Spain & León & San Miguel de las Dueñas & Boeza & 31/08/1994 & F. García-Criado & 29TQH01 & 570 \\
\hline Spain & León & Puente de Domingo Florez & Cabrera & $15 / 06 / 2005$ & D. Miguélez & 29TPG89 & 370 \\
\hline Spain & León & Castroquilame & Cabrera & $16 / 06 / 2005$ & D. Miguélez & 29TPG89 & 420 \\
\hline Spain & León & Llamas de Cabrera & Cabrera & $16 / 06 / 2005$ & D. Miguélez & 29TPG99 & 600 \\
\hline Spain & Madrid & Villamantilla & Perales & 1987-1989 & T. López et al. & 30TVK06 & 450 \\
\hline Spain & Madrid & El Pardo & Manzanares & $1987-1990$ & T. López et al. & 30TVK38 & 575 \\
\hline Spain & Guadalajara & Gascueña de Bornova & Bornova & $30 / 07 / 2001$ & M. Navarro & 30TVL95 & 1000 \\
\hline Spain & Guadalajara & Gascueña de Bornova & Bornova & $21 / 05 / 2002$ & J.L. Moreno & 30TVL95 & 1000 \\
\hline Spain & Guadalajara & Gascueña de Bornova & Bornova & 08/05/2009 & J.L. Moreno & 30TVL95 & 1000 \\
\hline Spain & Guadalajara & Valverde de los Arroyos & Sorbe & $21 / 05 / 2002$ & J.L. Moreno & 30TVL85 & 1075 \\
\hline Spain & Guadalajara & Cantalojas & Lillas & $22 / 05 / 2007$ & F. Picazo & 30TVL76 & 1350 \\
\hline Spain & Toledo & Hontanar & Estena & $25 / 07 / 2000$ & P. Aguilera & 30SUJ67 & 720 \\
\hline Spain & Toledo & Hontanar & Estena & 08/07/2008 & A. Millán et al. & 30SUJ68 & 700 \\
\hline Spain & Toledo & Hontanar & Pusa & $13 / 05 / 2002$ & J.L. Moreno & 30SUJ57 & 860 \\
\hline Spain & Toledo & Los Navalucillos & Pusa & 09/07/2008 & A. Millán et al. & 30SUJ57 & 860 \\
\hline Portugal & Vila Real & Vila Pouca de Aguiar & Corgo & $13 / 05 / 1987$ & N. Nieser & 29TPF18 & 700 \\
\hline Portugal & Viana do Castelo & Vila Praia de Áncora & Áncora & 08/05/1993 & D.T. Bilton & 29TNG12 & 25 \\
\hline Portugal & Viana do Castelo & Montaria & Áncora & 24/07/1998 & I. Ribera & $29 \mathrm{TNG} 22$ & 300 \\
\hline
\end{tabular}

Aphelocheirus sp.: Iberian endemic lineage distributed in the north of the Iberian Peninsula: Álava, Guipúzcoa and Burgos (Fig. 8). There is an old record of A. aestivalis from Asturias (Fernández, 1982) which could belong to this lineage due to the limestone calcareous nature of river where it was found. However, the material was unable to be reviewed (see discussion section). Table 4 shows the Iberian records of Aphelocheirus sp.

$1^{\text {st }}$ record for the Iberian Peninsula: North basin, Millán et al. (2002). 
TABLE 3. Iberian records of A. murcius.

\begin{tabular}{llllllll}
\hline Country & Province & Locality & River & Date & Collected by & U.T.M. & Alt. (m) \\
\hline Spain & Albacete & Molinicos & Mundo & $11 / 10 / 1982$ & C. Montes et al. & 30 SWH66 & 750 \\
Spain & Albacete & La Alfera & Mundo & $20 / 03 / 1983$ & C. Montes et al. & 30 SWH66 & 850 \\
Spain & Albacete & Yeste & Tús & $21 / 07 / 1983$ & C. Montes et al. & 30 SWH54 & 780 \\
Spain & Albacete & Yeste & Tús & $22 / 07 / 1983$ & C. Montes et al. & 30 SWH55 & 650 \\
Spain & Albacete & La Alfera & Mundo & $30 / 04 / 1987$ & N. Nieser & 30 SWH66 & 750 \\
Spain & Albacete & Yeste & Tús & $27 / 04 / 1997$ & I. Ribera & 30 SWH44 & 820 \\
Spain & Albacete & Yeste & Tús & $19 / 09 / 2001$ & J.L. Moreno & 30 SWH44 & 820 \\
Spain & Albacete & Yeste & Tús & $09 / 04 / 2009$ & P. Abellán \& N. Martínez & 30 SWH44 & 800 \\
Spain & Albacete & La Alfera & Mundo & $28 / 04 / 2009$ & A. Millán \& J.A. Carbonell & 30 SWH66 & 750 \\
Spain & Albacete & Yeste & Tús & $03 / 08 / 2010$ & O. Belmar et al. & 30 SWH44 & 820 \\
Spain & Albacete & Yeste & Tús & $03 / 08 / 2010$ & O. Belmar et al. & 30 SWH54 & 780 \\
Spain & Albacete & La Alfera & Mundo & $05 / 08 / 2010$ & O. Belmar et al. & 30 SWH66 & 750 \\
Spain & Cádiz & Jerez de la Frontera & Majaceite & verano 2000 & J.C. Salamanca et al. & 30 STF65 & 130 \\
Spain & Málaga & Algatocín & Genal & $30 / 08 / 2007$ & A. Castro et al. & 30 STF94 & 260 \\
Spain & Málaga & San Pedro de Alcántara & Guadaiza & $19 / 08 / 2009$ & A. Castro et al. & 30 SUF24 & 300 \\
\hline
\end{tabular}

TABLE 4. Iberian records of Aphelocheirus sp.

\begin{tabular}{|c|c|c|c|c|c|c|c|}
\hline Country & Province & Locality & River & Date & Collected by & U.T.M. & Alt. (m) \\
\hline Spain & Álava & Ozaeta & Barrundia & $18 / 05 / 1988$ & E. Rico & 30TWN45 & 560 \\
\hline Spain & Guipúzcoa & Aizarnazabal & Urola & $13 / 06 / 1988$ & E. Rico & 30TWN68 & 20 \\
\hline Spain & Guipúzcoa & Venta de Janoy & Bidasoa & 02/11/1988 & E. Rico & 30TWN68 & 60 \\
\hline Spain & Guipúzcoa & Endarlatza & Bidasoa & 03/11/1988 & E. Rico & 30TXN09 & 5 \\
\hline Spain & Burgos & Espinosa de los Monteros & Trueba & $21 / 03 / 2006$ & D. Miguélez et al. & 30TVN57 & 775 \\
\hline Spain & Burgos & Valle de Sedano & Ebro & 07/07/2008 & D. Miguélez et al. & 30TVN34 & 700 \\
\hline Spain & Burgos & Valle de Sedano & Ebro & 07/07/2008 & D. Miguélez et al. & 30TVN33 & 650 \\
\hline Spain & Burgos & Valle de Sedano & Ebro & 07/07/2008 & D. Miguélez et al. & 30TVN43 & 630 \\
\hline Spain & Burgos & Valle de Sedano & Ebro & 07/07/2008 & D. Miguélez et al. & 30TVN44 & 630 \\
\hline Spain & Burgos & Junta de Traslaloma & Ebro & 08/07/2008 & D. Miguélez et al. & 30TVN44 & 620 \\
\hline Spain & Burgos & Villarcayo de Merindad & Ebro & $10 / 07 / 2008$ & D. Miguélez et al. & 30TVN54 & 590 \\
\hline Spain & Burgos & Frías & Ebro & $10 / 07 / 2008$ & D. Miguélez et al. & 30TVN73 & 525 \\
\hline Spain & Burgos & Pesquera de Ebro & Ebro & $02 / 09 / 2010$ & A. Millán et al. & 30TVN43 & 650 \\
\hline
\end{tabular}

A. aestivalis: Western half of the Palearctic Region except Iberian Peninsula, North Africa, Arabic Peninsula and south-western Asia (Aukema \& Rieger 1995) (Fig. 11). All the records from the Iberian Peninsula must to be referred to the species listed above.

\section{Discussion}

These results update current knowledge of the relationships and geographical distributions of the species of the genus Aphelocheirus in the Iberian Peninsula which, until now; have been involved in nomenclatural and taxonomic confusion. First, A. occidentalis presents clear external differences, such as colour pattern and very long conexives, which permit it to be distinguished easily from other Aphelocheirus species. A. occidentalis is restricted to the centre and west of the Iberian Peninsula within the Hercynian region (see Ribera, 2000 for details about biogeographic regions in the Iberian Peninsula), and seems to prefer rivers with siliceous substrates. 
On the other hand, A. murcius and A. aestivalis are both morphologically and ecologically quite similar, and it is more difficult to distinguish between them. Nevertheless, the different left paramere shape and molecular analyses presented in this study confirm the taxonomic validity of $A$. murcius.
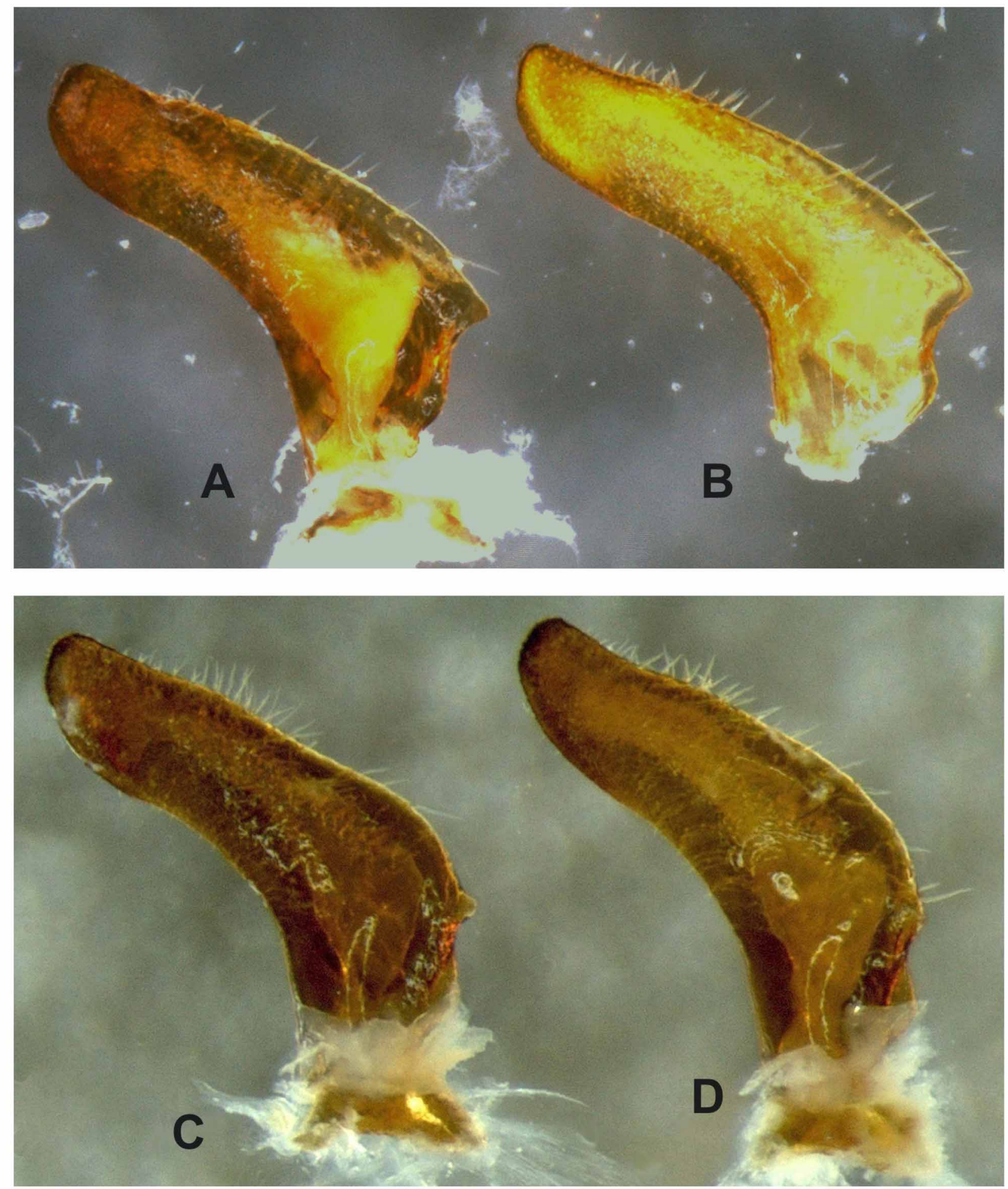

FIGURE 6. Left paramere of A) Aphelocheirus sp.; B) A. murcius; C) A. aestivalis (La Manche, France); D) A. aestivalis (Corsica). 

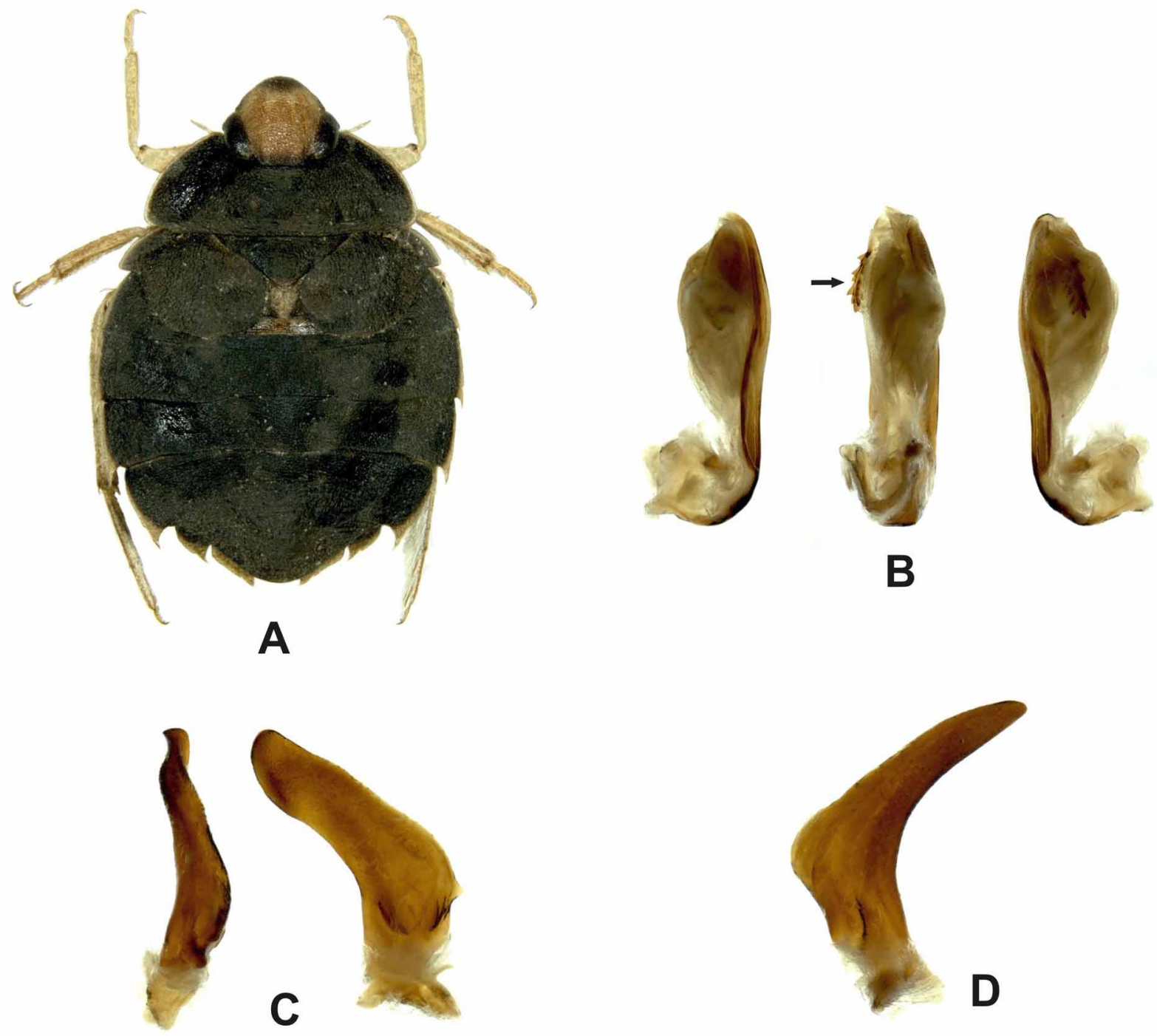

FIGURE 7. Aphelocheirus aestivalis. A) habitus; B) penis (ventral and lateral view); C) Left paramere (dorsal and lateral view); D) right paramere.

Nieser \& Millán (1989) distinguish several morphological differences between both species which were used in the description of A. murcius: (i) A. murcius: yellowish head and antennae with broad, yellowish lateral bands in thorax and abdomen, slightly pronounced lateral edge of embolium in micropterous, and genitalia with pointed left paramere heel; (ii) A. aestivalis: yellowish head and antennae without broad yellowish lateral bands in thorax and abdomen, very pronounced lateral edge of embolium in micropterous, and genitalia with a rounded left paramere heel.

After a comparative morphological analysis of recent material from both species, two common colour patterns in A. murcius and A. aestivalis were found: (i) yellowish head and antennae, greyish thorax and abdomen with large, yellowish lateral bands and yellowish marks in the pronotum and posterior half of abdomen (Fig. 9A,C,D); and (ii) yellowish head and antennae, dark greyish thorax and abdomen with very thin yellowish lateral bands (Fig. 9B,E); the yellowish marks can extend to dominate the greyish colour. These two patterns are independent of the specimen's sex and are present in the same population. The study of the embolium also did not show differences between the species, since individuals with a very pronounced lateral embolium edge and individuals with a less pronounced edge were found in populations of both species (Fig. 10). Analysis of the genitalia did not show differences in penis or right paramere. However, unambiguous differences were found in the shape of the left paramere 
heel, which was clearly pointed in A. murcius and rounded in A. aestivalis. This difference was corroborated in all studied individuals, with the exception of one specimen of $A$. aestivalis from the French Manche, which presented a little tooth in the heel of the left paramere (Fig. 6C), although obviously different to those from A. murcius (Fig. 6B). Hence, after analysing the morphological characteristics between A. murcius and A. aestivalis, it was found that most of them are too confusing or inadequate to differentiate between the species. It was observed that only the genitalia, notably the heel shape of the left paramere, presented a clear difference among all studied individuals.

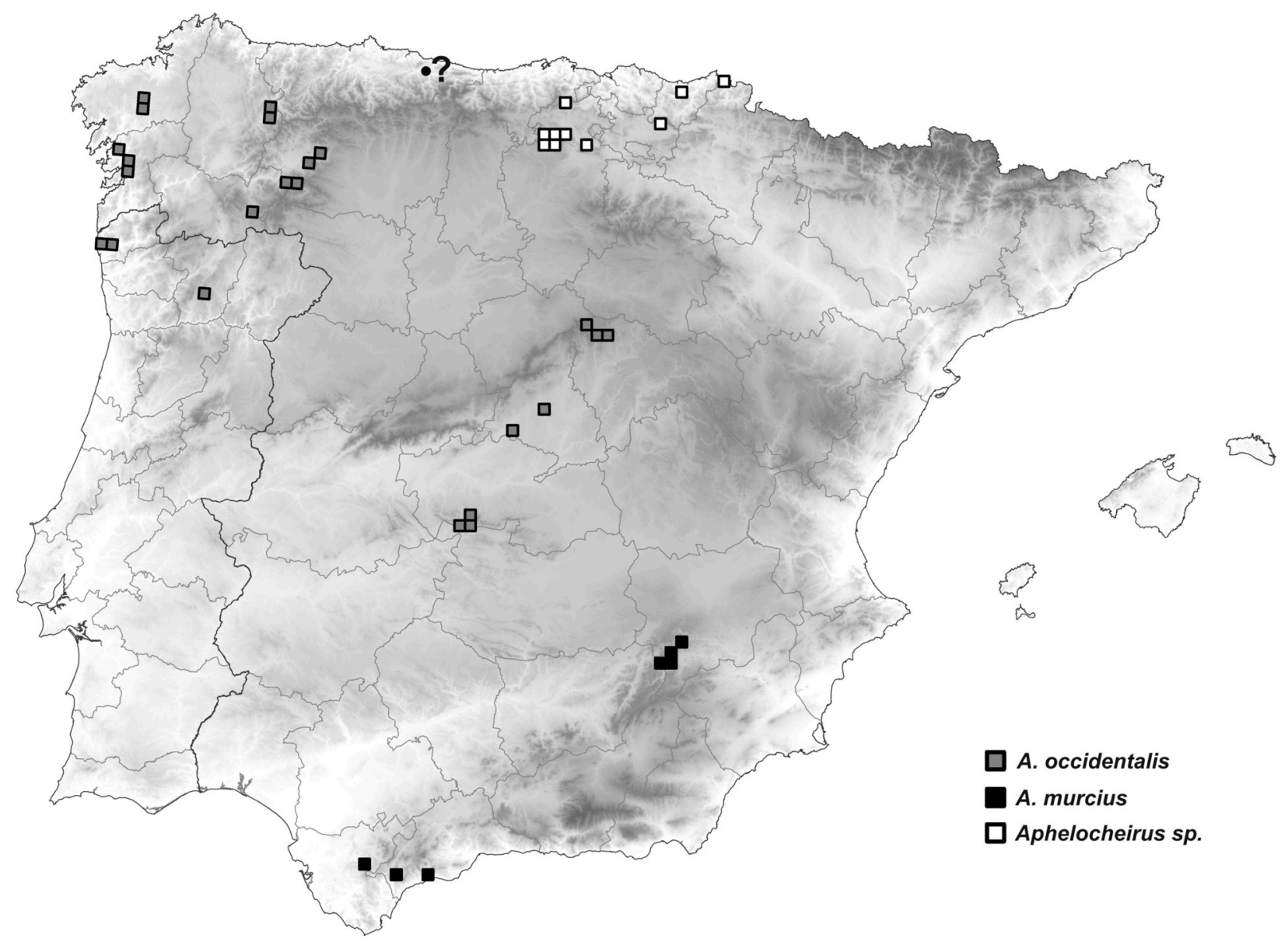

FIGURE 8. Distribution map of Iberian species of genus Aphelocheirus.

Following to the review of records and study of material of the genus Aphelocheirus in the study area, the presence of the species A. aestivalis in the Iberian Peninsula must be rejected. The first record of Aphelocheirus in the Iberian Peninsula was cited as A. aestivalis (Seabra, 1926) and documented in the Tras-os-Montes region of Portugal. This record, and those that followed, such as Seabra (1939) and Murillo (1985), seem to be incorrect. Although material could not be reviewed, according to the specimens analysed in this study in areas near to those referred to by Seabra $(1926,1939)$ and Murillo (1985), all the records of Aphelocheirus from the northwestern Iberian Peninsula may correspond to A. occidentalis. Elsewhere in the peninsula, there is no doubt that the revised specimens from the top section of the Segura and Ebro basins, southern Spain and the Basque Country do not belong to A. aestivalis. Some doubts exist regarding the identity of an old record of A. aestivalis from Asturias (Fernández, 1982) because this material also could not be reviewed. Nevertheless, the limestone nature of the river basin where it was located may indicate the presence of the Aphelocheirus sp. lineage in this region (see below). Therefore, A. aestivalis occurs in the western half of the Palearctic Region, except in the Iberian Peninsula, North Africa, Arabic Peninsula and southwestern Asia.

Molecular relationships between A. murcius and A. aestivalis showed three well-supported clades in the Iberian Peninsula (Fig. 11). Southern specimens of A. murcius (where this species was described) and those of A. aestivalis represent two independent sister lineages, which present a genetic divergence of around $1,5 \%$. This divergence is similar, for example, to those found among morphologically well-characterised endemic Iberian 

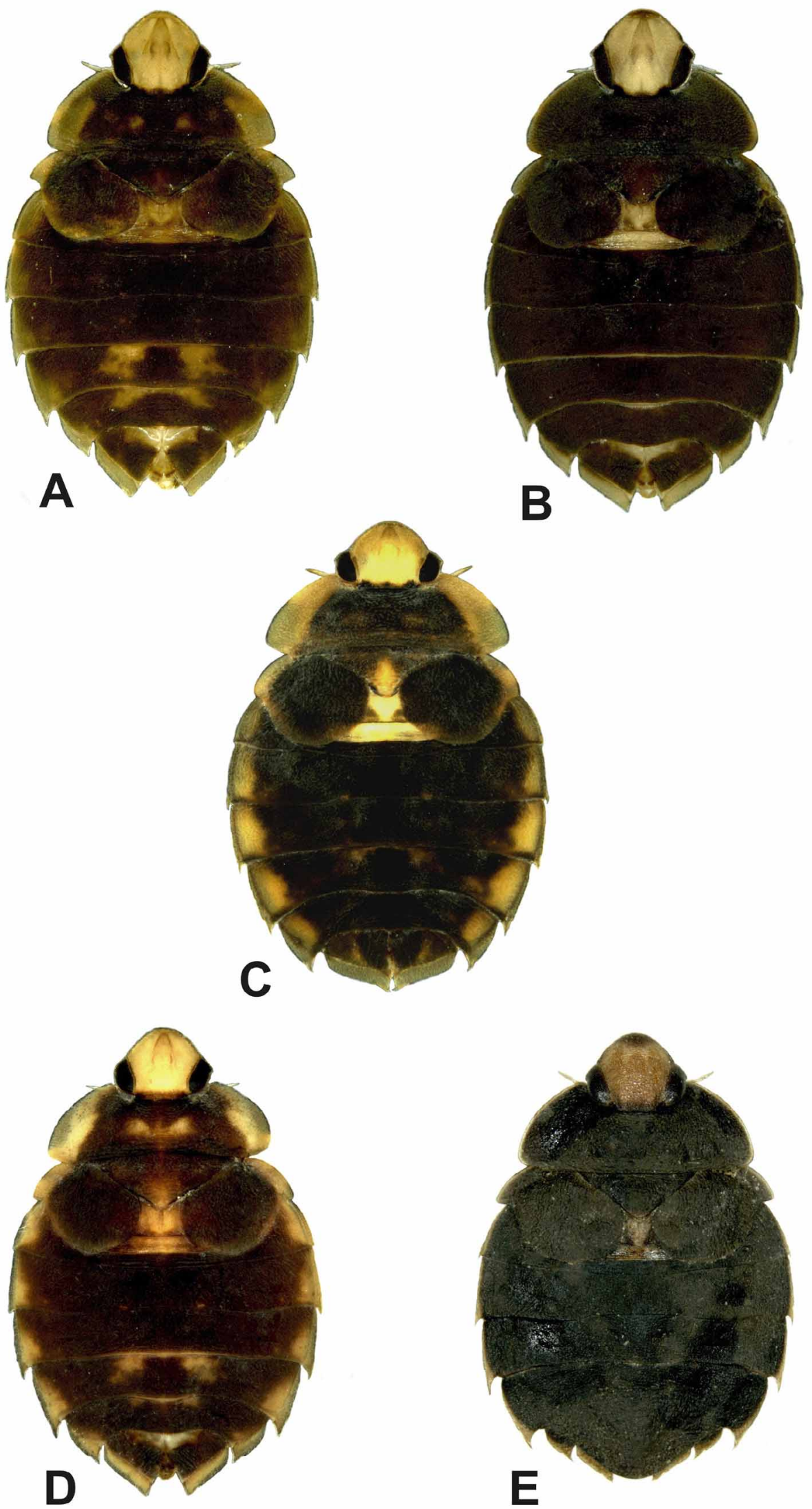

FIGURE 9. Color patherns of A,B) Aphelocheirus sp. (Ebro river, Burgos); C) Aphelocheirus murcius (Mundo river, Albacete); D) Aphelocheirus aestivalis (Corsica); E) Aphelocheirus aestivalis (La Manche, France). 

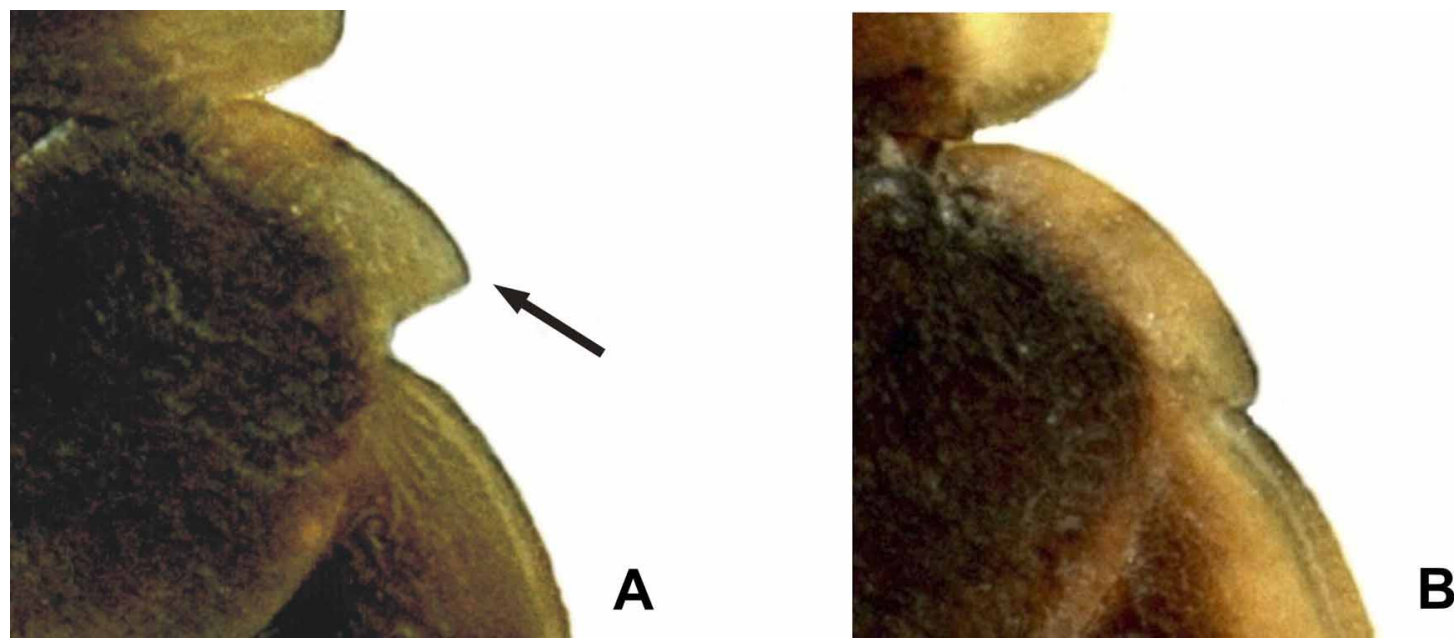

FIGURE 10. Lateral edge of embolium. A) strongly pronounced in A. murcius; B) weakly pronounced in A. aestivalis.

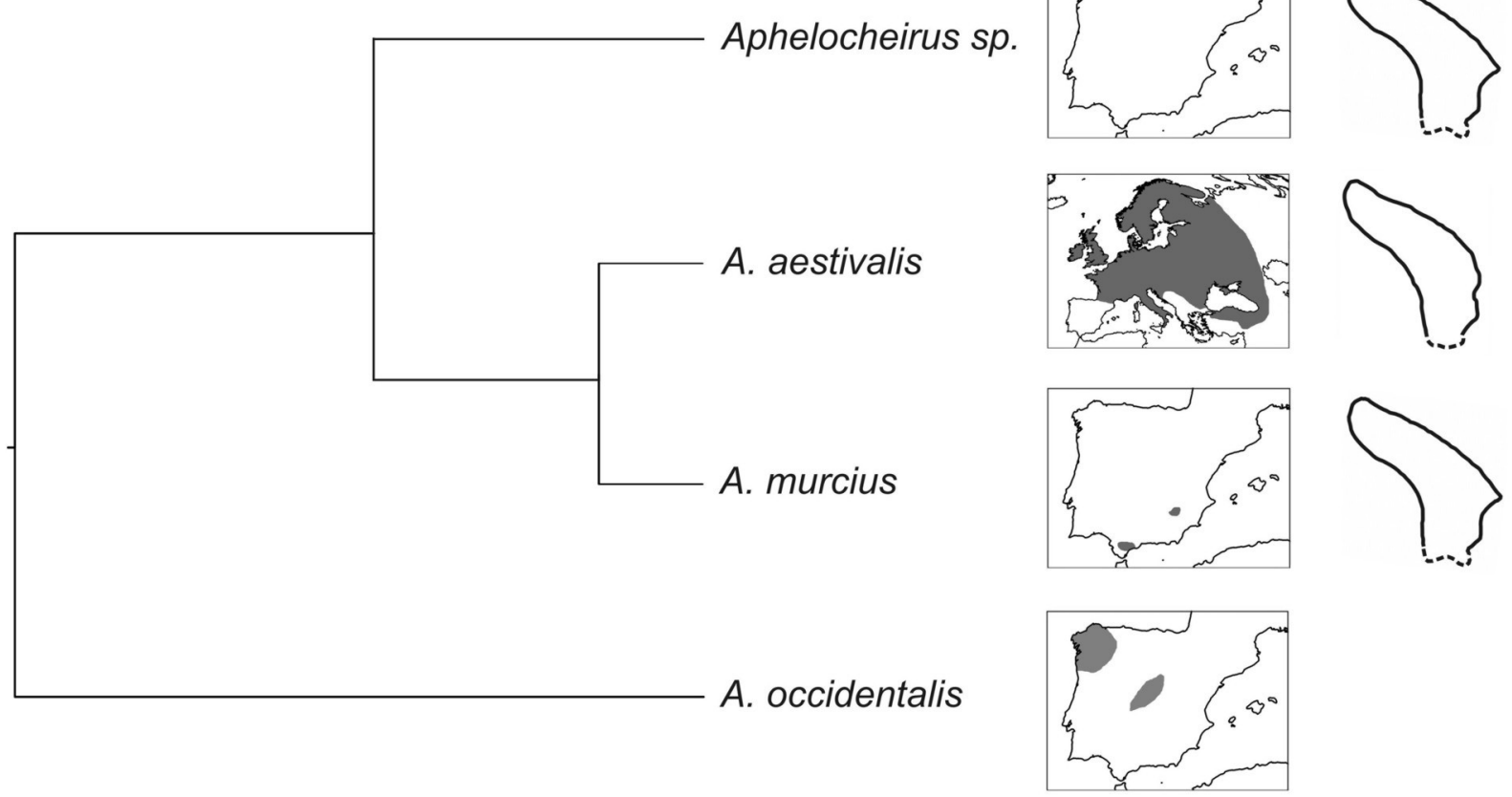

FIGURE 11. Phylogenetic relationships, distribution maps and left parameres of Aphelocheirus sp., A. aestivalis, A. murcius and $A$. occidentalis (no left paramere showed).

species of water beetle species (Ribera \& Vogler 2004). The genetic differentiation of both species is in agreement with the morphological differences found between them (notably the shape the left paramere), and confirm the taxonomic validity of $A$. murcius.

Unexpectedly, specimens of Aphelocheirus from Northern Spain, previously identified as A. murcius according to morphology (Carbonell \& Millán 2010), formed an independent sister lineage to the clade encompassing $A$. murcius (in southern populations) and A. aestivalis, with a divergence of around 5,6\%. Despite the strong genetic divergence of this lineage, consistent morphological differences between specimens within this lineage and those of A. murcius (both lineages share the pointed shape of the left paramere) could not be found. In fact, this lack of clear morphological differences between both entities resulted in the assignation of Aphelocheirus specimens from the north of the Iberian Peninsula to A. murcius in previous studies. Similarly, ecological preferences do not seem to be divergent between the lineages, who occupy similar microhabitats in limestone rivers. Since A. aestivalis and A. murcius are recognised as separate species, then populations of this lineage can be considered also as a distinct 
species. However, extreme caution should be exercised when describing taxa from molecular differences exclusively (but see Cook et al. 2010), and the lack of clear morphological differences, together with the lack of additional genetic data from other molecular markers and information concerning ecological differentiation, prevents us from naming this lineage as a new taxa. The potential taxonomic implications of these results, still difficult to reconcile with our current knowledge of morphological variation within Aphelocheirus, will be the focus of future research aided with the analysis of nuclear markers, additional European taxa, and the ecology of the different populations of the species.

Recent studies have considered A. murcius and A. occidentalis to be endangered in the Iberian Peninsula due to their limited geographical ranges and high habitat specificity (Carbonell \& Millán 2010). The assignation of the Aphelocheirus specimens from northern Spain to a distinct evolutionary entity suggests a new scenario to describe the distribution and conservation status of the genus Aphelocheirus in Iberian Peninsula. As a result, a new endangered Iberian endemism has been incorporated, and, at the same time, the geographical range of A. murcius has been reduced. Thus, A. murcius would be restricted to the south and southeast of the Iberian Peninsula within the Southeast biogeographical region (see Ribera 2000), and the northern lineage would be restricted to northern Iberia, while both species inhabit rivers with calcareous substrates.

Further studies including phylogenetic (using additional molecular markers like nuclear genes), morphological (focusing on microstructures and internal morphology), physiological, ecological and biogeographical approaches are necessary to understand the origin and evolution of species within the Aphelocheirus genus.

\section{Acknowledgements}

We thank David T. Bilton, David Miguélez, José Luís Moreno, Andrés Mellado and Félix Picazo for the borrowed material. We also wish to thank David Sánchez-Fernández and Carmelo Andújar for their help and suggestions about mapping and phylogenetic analysis. Manuel Baena, Agustín Castro, Andrés Mellado and David Miguélez gave us unpublished information about distribution of A. murcius and A. occidentalis. We also wish to thank Ignacio Ribera and Water and Cave Beetles Evolution Lab (Institut de Biologia Evolutiva, CSIC-UPF) for providding support with molecular analyses. This work was partially supported by funding from a predoctoral FPU grant to J.A. Carbonell. P. Arribas has also funded by a FPU predoctoral grant, P. Abellán have funded by postdoctoral grant, from the Fundación Séneca (Mucia, Spain). This work was also supported by funding from projects CGL2006-04159 (Ministerio de Educación y Ciencia) and 023/2007 (Ministerio de Medio Ambiente).

\section{References}

Andersen, N.M. \& Weir, T.A. (2004) Australian Water Bugs: their biology and identification (Hemiptera-Heteroptera, Gerromorpha \& Nepomorpha). Apollo Books, CSIRO Publishing: Collingwood, Victoria.

Aukema, B. \& Rieger, C. (1995) Catalogue of the Heteroptera of the Paleartic Region. Vol. 1: Enicocephalomorpha, Dipsocoromorpha, Nepomorpha, Gerromorpha and Leptopodomorpha. Netherlands Entomological Society, Ámsterdam, 222 pp.

Bergevin, E. (1925) Description d'une nouvelle espèce d'Aphelocheirus (Hémiptère Naucoridae) du Maroc. Bulletin de la Société d'Histoire Naturelle de l'Afrique du Nord, 16, 80-84.

Carbonell, J.A. \& Millán, A. (2010) Aphelocheirus murcius Nieser \& Millán, 1989 y Aphelocheirus occidentalis Nieser \& Millán, 1989 (Hemiptera: Aphelocheiridae) dos hemípteros acuáticos endémicos de la Península Ibérica amenazados. Boletín de la Sociedad Entomológica Aragonesa, 46, 429-435.

Cook, L.G., Edwards, R.D., Crisp, M.D. \& Hardy, N.B. (2010) Need morphology always be required for new species descriptions?. Invertebrate Systematics, 24, 322-326.

Fabricius, J.C. (1794) Entomilogia systematica emendata et auctea, secundum classes, ordines, genera, species adjecties synonymis, locis, observationibus, descriptionibus, vol 4, Christ. Gottl. Proft, Hafniae. 472 pp.

Fernández, C. (1982) Heterópteros acuáticos y semiacuáticos de Asturias (N. España). I. Catálogo sistemático. Boletín de la Real Sociedad Española de Historia Natural (Sec. Biología), 80, 211-218.

Huelsenbeck, J.P. \& Ronquist, F. (2001) MRBAYES: Bayesian inference of phylogenetic trees. Bioinformatics, 17, 754-755.

Larsen, O. (1927) Über die Entwicklung und Biologic von Aphelocheirus aestivalis Fabr. Entomologisk Tidskrift, 48, 181-205.

Larsen, O. (1931) Beiträge zur Oekologie und Biologie von Aphelocheirus aestivalis Fabr. International Review of Hydrobiology, 26, 1-19. 
López, T., Costas, M. \& Vázquez, M.A. (1995) Nepomorpha y Gerromorpha de la Provincia de Madrid. Contribución al conocimiento de la biodiversidad entomológica ibérica (Heteróptera). Avances en Entomología Ibérica, 221-228.

Miguélez, D. \& Valladares, L.F. (2006) Nuevos datos sobre la distribución geográfica y el hábitat de Aphelocheirus occidentalis Nieser \& Millán, 1989 (Hemiptera: Aphelocheiridae). Boletín Sociedad Entomológica Aragonesa, 38, 343-344.

Millán, A., Moreno, J.L. \& Velasco, J. (2002) Estudio faunístico y ecológico de los coleópteros y heterópteros acuáticos y semiacuáticos de la provincia de Albacete. Instituto de Estudios Albacetenses, $180 \mathrm{pp}$.

Millán, A., Velasco, J., Nieser, N. \& Montes, C. (1988) Heterópteros acuáticos (Gerromorpha y Nepomorpha) de la cuenca del río Segura, S. E. España. Anales de Biología, 15 (4), 74-89.

Murillo, J. (1985) Algunes captures d’heteròpters aquàtics efectuades a catalunya i altres localitats de la resta de la península ibérica. Butlletí Institució Catalana d'História Natural (Sec. Zoología), 52, 139-147.

Nieser, N., Baena, M., Martínez-Avilés, J. \& Millán, A. (1994) Claves para la identificación de los heterópteros acuáticos (nepomorpha \& gerromorpha) de la Península Ibérica-Con notas sobre las especies de las Islas Azores, Baleares, Canarias y Madeira. Asociación Española de Limnología, Madrid, 112 pp.

Nieser, N. \& Millán, A. (1989) Two new species of Aphelocheirus from the Iberian Peninsula (Heteroptera: Naucoridae). Entomologische Bergische, 49, 111-117.

Nieser, N. \& Montes, C. (1984) Lista faunística y bibliográfica de los Heterópteros acuáticos (Nepomorpha y Gerromorpha) de España y Portugal. Asociación Española de Limnología. Madrid, 69 pp.

Posada, D. (2008) jModelTest: Phylogenetic model averaging. Molecular Biology and Evolution, 25, 1253-1256.

Ribera, I. (2000) Biogeography and conservation of Iberian water beetles. Biological Conservation, 92, 131-150.

Ribera, I. \& Vogler, A.P. (2004) Speciation of Iberian diving beetles in Pleistocene refugia (Coleoptera, Dytiscidae). Molecular Ecology, 13, 179-193.

Ronquist, F. \& Huelsenbeck, J.P. (2003) MrBayes 3: Bayesian phylogenetic inference under mixed models. Bioinformatics, 19, 1572-1574.

Salamanca, J.C., Cano, F.J. \& Ferreras, M. (2002) Heterópteros acuáticos del Parque Natural de Los Alcornocales: datos preliminares. Almoraima, 27, 365-369.

Seabra, A.F. (1926) Hémiptères Hétèropteres de la province de Tras-os-Montes. Memorias e estudos do Musen Zoológico da Universidade de Coimbra, Ser, 1, 5-39.

Seabra, A.F. (1939) Contribução para a história da entomologia em Portugal. Publicaçao da Direcçao Geral dos Servicios Florestais e Aquicolas, 6, 155-302.

Simon, C., Frati, F., Beckenbach, A., Crespi, B., Liu, H. \& Flook, P. (1994) Evolution, Weighting, and Phylogenetic Utility of Mitochondrial Gene-Sequences and A Compilation of Conserved Polymerase Chain-Reaction Primers. Annals of the Entomological Society of America, 87, 651-701.

Stamatakis, A. (2006) RAxML-VI-HPC: Maximum likelihood-based phylogenetic analyses with thousands of taxa and mixed models. Bioinformatics, 22, 2688-2690.

Stamatakis, A., Hoover, P. \& Rougemont, J. (2008) A Rapid Bootstrap Algorithm for the RAxML Web Servers. Systematic Biology, 57, 758-771. 